réaliser son programme, faire oeuvre constructive et „éclairer efficacement ceux qui ont charge d'ajuster les rapports délicats entre l'économique et l'humain, entre l'ordre technique et le mieux-être social".

\title{
PROGRAM FOR RESEARCH
}

\author{
IN THE HISTORY OF THE COMMUNIST PARTY \\ OF THE SOVIET UNION, I $955-56$
}

A short-term Research Program on the History of the CPSU has been inaugurated by an inter-university committee of scholars, consisting of Merle Fainsod (Harvard University), Harold H. Fisher (The Hoover Institute and Library), Philip E. Mosely (New York City) and Geroid T. Robinson (Columbia University), with the financial support of the Ford Foundation.

In order to promote the systematic and expeditious completion of studies relevant to the history of the CPSU, the committee is now able to offer modest grants in aid of research, along the following lines:

I. a limited number of full-time fellowships, pre-doctoral and postdoctoral, on a one-year basis, particularly to facilitate the completion of pertinent research projects which are already well under way. (As a rule, the Program will not be able to support research projects in their beginning stage);

2. grants for a semester, relieving recipients completely of their academic duties for that period and enabling them to devote the period to the completion of research work that was previously well advanced;

3. assistance in securing access to otherwise inaccessible research materials;

4. a limited number of summer grants, for subsistence and travel, to facilitate access to sources and completion of manuscripts already in an advanced stage.

Applications will be considered from academically trained persons and from other persons who, by their previous research, have demonstrated a high level of competence in this field of investigation. Each applicant sould submit a detailed statement on (a) the purpose, scope and original contributions of his study, together with (b) a realistic estimate of the amount of work and support needed to complete it, and also (c) the names of persons best qualified to comment on his competence and on his project. 
HISTORY C.P.S.U.

Requests for application forms and any other correspondence should be addressed to: Research Project on the History of the CPSU, 40I West I i 8th Street, New York 27, New York.

ALFRED G. MEYER

October, 1955 .

Director 